\title{
Oprettelsen af Als-Ærø Bispedømme i 1819
}

\author{
af KARSTEN HERMANSEN
}

I året 1819 udskiltes øerne Als og Ærø fra Fyns Stift og udgiorde fra da af og indtil 1864 et selvstændigt bispedømme med kun atten kirker: tolv på Als og seks på Ærø. ${ }^{1}$ I den følgende artikel belyser cand.mag. Karsten Hermansen, Marstal, baggrunden for dannelsen af dette lille bispedømme.

\section{Indledning}

Fra begyndelsen af 1800-tallet havde man arbejdet på en forenkling af de forvirrede administrative forhold $i$ hertugdømmerne. Siden 1773 var Slesvig og Holsten som helhed blevet forvaltet af kongen og Tyske Kancelli. Før den tid var visse dele blevet regeret af hertuger af de sønderjyske fyrsteslægter. ${ }^{2}$ På grund af Det tyske Riges opløsning i 1806 lod kronprins Frederik (1768-1839, fra 1808 Frederik VI) udstede patentet af 9 . september 1806, hvorved Holsten fremtidigt skulle være en uadskilt del af monarkiet. Det gav et dårligt forhold til kronprinsens svoger, hertug Frederik Christian (1765-1814) af Augustenborg, som i statsrådet forsøgte at få sin hertuglinies arverettigheder anerkendt. ${ }^{3}$ Nationalt og sprogligt set var det af stor betydning, at skoleloven af 24 . august 1814 for Slesvig og Holsten gennemførtes. Kirkesprogsgrænsen nord om Bov og syd om Tønder blev herved trukket skarpt op. Tidligere dansktalende i Sydslesvig fik af denne grund en hurtigere overgang til tysk talesprog. ${ }^{4}$

Særligt indviklede var forholdene på Als og Ærø, da øerne havde forskellig verdslig og gejstlig jurisdiktion. I verdslig henseende var øerne underlagt hertugdømmernes jurisdiktion, medens de i gejstlig henseende - bortset fra to sogne - hørte under Fyns Stift. Det betød, at kirke- og skolevæsen fulgte dansk lov og stod under Danske Kancelli. Alt andet fulgte hertugdømmernes lovgivning og henhørte under Tyske Kancelli, som fra 1806 benævntes Slesvig-Holstenske Kancelli og fra 1816: Slesvig-Holsten-Lauenburgske Kancelli. ${ }^{5}$

Ærø hørte i sin helhed under Fyns Stift, men det gjorde Als ikke. 
og Ærø. En række forskellige synsvinkler på dette spørgsmål dannede tilsammen det grundlag som Danske Kancelli og kongen i sidste instans afgjorde sagen ud fra.

I det følgende samler interessen sig om, hvorfor man oprettede en ny bispestol i 1819. Spørgsmålet skal søges besvaret udfra en gennemgang af nogle væsentlige faktorer for den kirkelige administration på øerne Als og Ærø: hertugens patronatsrettigheder over kirke og skole, de sproglige, nationale og undervisningsmæssige spørgsmål, de økonomiske omstændigheder samt de administrative og jurisdiktionelle forhold.

I modsætning til den eksisterende litteratur om bispedømmets oprettelse - der i høj grad lægger vægt på personlige hensyn som afgørende for stiftets dannelse - vil denne artikel i stedet betone de administrative og jurisdiktionelle problemers reelle betydning for AlsÆrø Bispedømmes oprettelse.

\section{Litteratur}

Bispedømmets oprettelse er ikke vist megen opmærksomhed $\mathrm{i}$ almene fremstillinger om perioden. H.N. A. Jensen omtaler bispedømmets oprettelse i sin Schleswig-Holsteinische Kirchengeschichte (1879), ${ }^{9}$ men giver ingen vurdering af årsagerne til oprettelsen. Tilsvarende gælder det i Harald Jørgensens Lokaladministrationen i Danmark (1985). ${ }^{10}$

M. Mackeprang udgav i 1952 artiklen "Biskop Jørgen Hansen. Et foredrag «. Det var hans opfattelse, at bispedømmet først og fremmest blev oprettet af hensyn til den unge hertug Christian August (17981869), så denne var fritaget for at forhandle med en så underordnet embedsmand som en amtsprovst. En biskop var mere acceptabel. ${ }^{11}$ Mackeprang vurderer sagen tilsvarende i 1954 i artiklen "Sønderjyllands politiske og administrative forhold «. ${ }^{12}$

Anne Riising har $\mathrm{i}$ artiklen "Om Ærøs jurisdiktionsforhold indtil 1866“ (1964) ikke givet nogen vurdering af årsagerne til oprettelsen af bispedømmet, men derimod understreget, at Ærø dermed var helt løst fra Fyns Stift. ${ }^{13}$

Det stik modsatte syn hævder Niels Knud Andersen i "Biskop over Als og Erø« (1972). Han forsøger at sandsynliggøre en fortsat fynsk tilknytning udfra benævnelsen bispedømme i stedet for stift. Det vil sige, at Als og Frø skulle udgøre et eget bispedømme inden for Fyns Stift. Om oprettelsen af bispedømmet er Andersen en smule mere 
nuanceret end tidligere, men har stadig hovedvægten på hensynet til hertugen. ${ }^{14}$

Det mest nuancerede syn stammer fra H.P. Clausens artikel i Sønderjyske Årbøger: "Dansk og tysk på Als 1812-48« (1965). Heri får man en fremragende gennemgang af perioden fra 1812 til 1819, hvor bispedømmet blev oprettet. Clausen interesserer sig for skolehistorien, men via den tætte historiske tilknytning til kirken, får man et klart indblik i forhandlingerne om den administrative omlægning på øerne. Clausen er lidt vag i sin konklusion vedrørende bispedømmets oprettelse, men har dog overvejende vægten på de sproglige hensyn og på en simplere administration. Ikke desto mindre dukker også her hensynet til hertugen op. ${ }^{15}$ I bogen Augustenborgerne. Slxgt - Slotte - Skxbne (1980) er H. P. Clausen mere klar i sin konklusion: "Man håbede, at det ville gøre hertugen mere fremkommelig, når han skulle forhandle med en biskop og ikke med en amtsprovst«. ${ }^{16}$

Kort sagt: Mackeprangs teori om hensynet til hertugen er blevet stående som den toneangivende årsagsforklaring til spørgsmålet om oprettelsen af Als-Ærø Bispedømme.

Endelig skal G. Japsen: Det dansksprogede skolevæsen $i$ Sønderjylland indtil 1814 (1968) fremhæves for sin fine gennemgang af forhandlingsforløbet. Man må desværre undvære Japsens vurdering af årsagen til embedsoprettelsen, da han slutter i 1814.

\section{Årene 1803-1819 i hovedtræk}

I 1803 gjorde man et forste forsøg på at få startet forhandlinger om en forenkling af tilstanden på Als og Ærø. Danske Kancelli henvendte sig først til Tyske Kancelli, som derefter skrev til Overretten og Overkonsistoriet på Gottorp i februar 1804. Tanken var at lægge Als til Slesvig Stift i gejstlige sager, medens Ærø i verdslige sager skulle henlægges til Fyn. ${ }^{17}$ Gottorp indhentede betænkninger fra de berørte og meget enige - instanser. ${ }^{18}$ Sagen gik imidlertid i stå, da Tyske Rentekammer fandt det rigtigst, at spørgsmålet blev taget med i overvejelserne i den i 1798 nedsatte kommission angående grænseregulering mellem Jylland og hertugdømmet Slesvig. ${ }^{19}$

I 1812 blev spørgsmålet taget op igen. Denne gang var det aktualiseret af skolevæsenets forhold. Fyns biskop Plum (1760-1834) anmodede om, at det provisoriske skolereglement af 10. oktober 1806 for almueskolevæsenet på landet i Sjællands, Fyns og Lolland-Falsters 
stifter måtte indføres på Als og Ærø. ${ }^{20}$ Plum udtalte sig i den anledning negativt om øernes skolevæsen. Synspunkterne stammede fra den siden 1808 konstituerede provst Frederik Ebbesen (1768-1836) fra Svenstrup i Als Nørreherred. ${ }^{21}$ Dét følte hertugen på Augustenborg, Frederik Christian, krænkende. Snart efter udløste det en reaktion ${ }^{22}$ ikke mindst fordi han frygtede for sine patronatsrettigheder i Sønderherred.

Længere kom man ikke i 1812. Den 29. juli 1814 kom anordningen for almueskolevæsenet i Danmark. Den 24. august 1814 kom den tilsvarende for hertugdømmerne. Problemerne med indførelsen af skoleloven - og hvilken - gjorde, at man for alvor begyndte at gore sig overvejelser om Als og Ærøs fremtidige kirkelige og civilretlige tilknytning. 23

Resultatet blev i 1819 oprettelsen af et bispedømme for Als og \#rø samt nedsættelsen af en kommission til forenkling af øernes blandede forfatning. ${ }^{24}$ Når man valgte at oprette et så lille bispedømme, skyldtes det en række faktorer, som i det følgende skal beskrives. Derefter følger en vurdering af disse faktorers forholdsvise indflydelse på den valgte løsning.

\section{Det hertugelige patronat}

Hertugens patronatsret gav ret til udnævnelse af præster og lærere i patronatsområdet, som var Als Sønderherred. I praksis gav patronatsretten også bemyndigelse til udstedelse af skolereglementer for de enkelte skoler. Rettighederne stammede fra 1756 og 1764, hvor Frederik V overlod hertugen af Augustenborg størstedelen af Sønderherred som arveligt fideikommis. ${ }^{25}$

Med forordning af 3. juni 1809 ophævedes kalds- og birkeret for adelige og særskilte godsejere. Hertugen kunne herefter kun foreslå tre personer, som kongen valgte iblandt. ${ }^{26}$ Den hertugelige patronatsret var blevet stækket. Forholdet til kongehuset var samtidig konfliktfyldt på grund af spørgsmålet om hertugslægtens arverettigheder og indflydelse. ${ }^{27}$

Da biskop Plum i 1812 ytrede sig om skolevæsenets slette tilstand på øerne, svarede hertug Frederik Christian omgående, at han havde betalt for at have elever på landets seminarier, så de kunne give en kvalificeret undervisning i Sønderherred. Hertugen sluttede af med at kalde biskoppens skrivelse af 11. juni 1812 til 


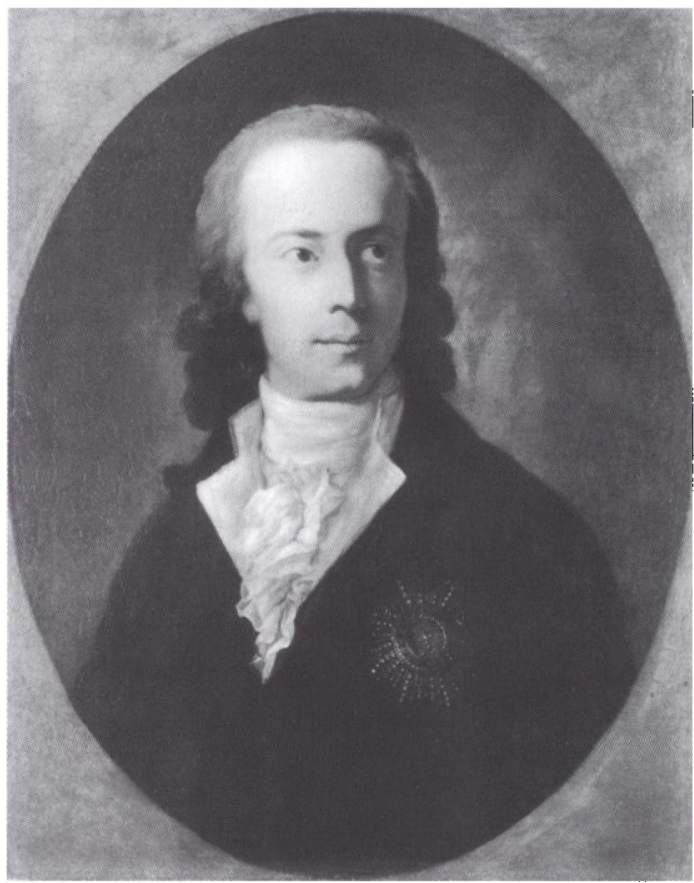

Hertug Frederik Christian of Augustenborg (17651814) udforte et stort arbejde indenfor uddannelsespolitikken, men kom efter 1806 i stadig større modsætningsforhold til kronprins Frederik (6.). Maleri af Anton Graff 1791. Foto $i$ Institut for sønderjysk Lokalhistorie.

Danske Kancelli krænkende og en sand fornærmelse for en mand, der havde opofret sine bedste år $\mathrm{i}$ skolevæsenets bestyrelse. ${ }^{28} \mathrm{Amt}-$ mand Linstow (1775-1848) i Sønderborg fandt også - i lighed med hertugen - biskoppens vurdering fejlagtig og afviste at sidde $i$ den foreslåede kommission til skolevæsenets forbedring. ${ }^{29}$ I oktober indså biskop Plum sin fejltagelse, da han var på visitatsrejse i området, og sagen blev stillet $\mathrm{i}$ bero.

De nye skolelove fra 1814 gav påny strid, idet den danske lovgivning formelt set skulle indføres på Als og Ærø. Overinspektør Petersen på Augustenborg gik imidlertid ind for at indføre hertugdømmernes skolelov, da den ville give mest enhed i forretningsgangen. Indførelsen af en ny skoleordning på øerne blev derfor foreløbig udsat.

I 1814 døde den gamle hertug. I den unge hertug Christian Augusts omgivelser frygtede man for at tabe den politiske indflydelse ved at acceptere en fortsat fordanskning af området. Lagdes Als helt til kongeriget, ville hertugens særlige fyrstelige rettigheder bortfalde og til- 
bage var kun en almindelig adelig godsejer. ${ }^{30}$ Derfor brugte hertugen megen energi på at undgå enhver form for indflydelse til kongelige embedsmænd. ${ }^{31}$

\section{Det danske sprog i kirke og skole}

Arkitekten bag biskop Plums henvendelse til Danske Kancelli - om skolevæsenets dårlige tilstand på Als og Ærø - var som tidligere nævnt den konstituerede provst i Als Nørreherred, Frederik Ebbesen i Svenstrup. Både den benyttede litteratur og kilderne rummer et væld af oplysninger om Svenstrup-præsten. Her skal kun gives en kort opsummering. ${ }^{32}$

Ebbesens utvetydige mål var at sikre Als og Ærøs fortsatte tilknytning til Fyns Stift, da det angiveligt ville sikre danskhedens bevarelse som skole- og kirkesprog. Ebbesens synspunkt var kort sagt nationalt betinget. Ebbesen frygtede for følgerne af en gejstlig tilknytning til Slesvig: præsterne skulle uddannes på universitetet $\mathrm{i}$ Kiel i stedet for i København. Tyske præster ville kunne ansættes, og det ville give vanskeligheder $i$ forhold til menigheden, som ikke forstod mere tysk end jyden eller fynboen. Tilsvarende gjaldt for skolelærerne. Den fortsatte tilknytning til Fyns Stift var eneste garanti for rent danske præster og skolelærere på øerne. ${ }^{33}$

Ebbesen forfulgte sit mål meget konsekvent. Han nægtede at følge amtmandens henstillinger og var derfor skyld $i$, at to lærerstillinger $i$ henholdsvis Oksbøl og Elstrup i 1814 stod ledige på femte og tredie år. Ebbesen kunne kun handle sådan på grund af den blandede jurisdiktion: gejstligt var han underlagt dansk lov, men amtmanden hørte under den verdslige slesvigske lovgivning og jurisdiktion. Ifølge amtmand Linstow skyldtes Ebbesens adfærd ønsket om at fremme egne planer. Dette var også motivet bag hans afskaffelse af de fra slesvigsk lov påbudte tolvmænd i Svenstrup sogn. Ebbesen undskyldte sig med, at han blot havde taget imod tolvmændenes tilbud om at nedlægge deres hverv, og derfor nøjedes med to medhjælpere i kirke-, skole- og fattigvæsensanliggender jvf. Danske Lov 2-9-2.34

Ved sin meget konsekvente og usmidige optræden havde Ebbesen meget klart synliggjort de problemer, som fulgte af den blandede forfatning. Taktikken styrkede imidlertid ikke stemningen for at lægge Als til Fyns Stift. Tværtimod: det var jo ham og ikke den verdslige jurisdiktion, som skabte vanskelighederne. 


\section{Det økonomiske perspektiv}

Da spørgsmålet om en forenkling af tilstanden på Als og Ærø blev taget op til overvejelse i 1804, skrev Nordborgs amtmand Ahlefeld en betænkning til Overretten. Heri opregnede han de økonomiske forhold, der ville få betydning for Nordborg Amts præster ved en jurisdiktionel ændring. ${ }^{35}$

Tilknytningen til Fyn var fordelagtig på flere måder: enkekassen, brandsocietetet, nådensåret, ${ }^{36}$ retten til en capellan pro persona og den gejstlige skiftejurisdiktion. ${ }^{37}$ Desuden var der en enkepensionsanstalt for degne og skolelærere. Alle var på daværende tidspunkt enige om, at de siddende præster og lærere skulle kunne bevare deres privilegier, hvis der blev gennemført en gejstlig tilknytning til Slesvig Stift, og at først déres efterfølgere skulle følge slesvigsk kirkelovgivning fuldt ud.

Et af de værste tab for præsterne ville være at miste capellan-rettigheden. Den sikrede, at en dansk præst kunne blive siddende i sit embede til sin død, medens en personlig capellan varetog embedet. En slesvigsk præst måtte derimod gå af ved alderdomssvækkelse og klare sig så godt som muligt, hvilket til tider kunne være vanskeligt. Til gengæld mente Ahlefeld, at reglerne for salg af præsteboliger var bedre i Slesvig, da man her ikke havde nogen maksimumspris som i Danmark. - Vel næppe nogen entydig fordel, da det afhang af, om man var køber eller sælger.

Man overvejede ikke en regulering alene for præsternes skyld. Langt vigtigere var derfor de almene økonomiske forhold, som fulgte med en eventuel jurisdiktionel ændring.

Amtmand Ahlefeld var en varm tilhænger af at lægge Als til Slesvig Stift og Ærø til Fyn i verdslige sager. Der var dog det økonomiske minus, at Ærøskøbings frihed fra licent og accise ville bortfalde, da disse rettigheder kun gjaldt for købstæder i hertugdømmerne. ${ }^{38}$

I 1816 lagde Tyske Rentekammer vægt på, at man ved at lægge Ærø verdsligt til Fyn dermed øgede jordbeskatningen af øens beboere voldsomt. På daværende tidspunkt skyldsattes beboerne efter plove, men ved en verdslig tilknytning til Danmark skulle skatten sættes i hartkorn. Det ville give Ærø en samlet skattebyrde på 134.786 Rbd. sølv, mod kun 36.133 Rbd. sølv ved den daværende slesvigske tilknytning. Beregningen tog udgangspunkt $i$, at en plov svarede til 12 tdr. hartkorn. Rentekammeret bemærkede også fordelen ved slesvigsk 
møntfod på Ærø.. ${ }^{39}$ Denne ville også gå tabt ved en sammenlægning med Danmark.

Alt $\mathrm{i}$ alt måtte resultatet blive, at den verdslige slesvigske lovgivning ikke måtte ophæves for øerne - så hellere bevare den blandede forfatning. ${ }^{40}$

\section{Det administrative og jurisdiktionelle aspekt}

Amtmanden i Nordborg understregede i 1804, at da de kongelige kirker på Ærø og i Nørreherred - i modsætning til Sønderherred - stod direkte under kongen, og da indtægterne herfra blev forvaltet i Rentekammeret, var det umuligt - selv med den samme forfatning - at administrere helt ensartet.

Ærø og Als havde begge de samme blandede forfatningsforhold og kunne derfor også i gejstlige sager begge uden videre lægges til Slesvig. Når amtmanden imidlertid gik ind for at lægge Als til Slesvig Stift og Ærø til Danmark, skyldtes det transportforholdene og dermed kommunikationsforbindelserne. Om vinteren kunne breve være unødig lang tid undervejs til Als. Det var derfor vanskeligt at administrere Ærø som en del af Nordborg Amt. Problemet lå i, at Ærøs forbindelser med omverdenen gik via Fyn, selv om afstanden til Als var den samme. Forbindelsen til Nordborg Amt var blevet svækket yderligere, da Ærø efter forordning af 18 . nov. 1773 havde fået egen embedsmand og ret. Det var et vægtigt argument, at det meste af Ærøs handel foregik med Fyn. Amtmandens bemærkning om det mere fremherskende danske sprog på Ærø end på Als kan diskuteres, hvis provst Ebbesens synspunkt skal have nogen gyldighed. ${ }^{41}$

I 1815 skrev Danske Kancelli til det Slesvig-Holstenske Kancelli og anmodede om at få en betænkning angående øernes blandede forfatning. Et af hovedpunkterne var, at forretningsgangen var for tung, når gejstligheden hørte under Danske Kancelli, medens amtmanden i gejstlige sager stod under Slesvig-Holstenske Kancelli og modtog ordrer via Overretten på Gottorp. ${ }^{42}$ Netop dette forhold havde muliggjort Ebbesens ovenfor beskrevne taktik og var derfor væsentligt at få ændret.

Rentekammerets økonomiske betænkeligheder ved at lægge Ærø til Fyn i verdslige sager er tidligere nævnt. Kammeret gjorde desuden et jurisdiktionelt og administrativt forhold gældende: en ændring af jurisdiktionen til danske love ville give besværligheder for ærøboer- 
nes indbyrdes forhold med hensyn til ejendomme og næringsvæsen, som nu var bestemt af slesvigske love. Ifølge Rentekammeret øgedes problemet af, at øens embedsmænd ikke var kendt med de danske love. ${ }^{43}$

\section{Als-Ærø Bispedømme oprettes}

Fyns Guvernement afgav i november 1816 en betænkning om Als og \#røs blandede forfatning til Danske Kancelli. Betænkningen var udtryk for et regulært kompromis, som forsøgte at tage hensyn til alle.

Øerne burde henlægges til henholdsvis Slesvig og Danmark. Løsningen med Als til hertugdømmet var oplagt, blot måtte man sikre, at »det danske Sprog ej fortrænges«. Det ville imidlertid næppe blive noget problem, da det tilsvarende forhold også gjorde sig gældende på Sundeved og i de fleste af hertugdømmet Slesvigs nordlige amter. På Ærø kunne de økonomiske ulemper ved en dansk verdslig lovgivning afhjælpes med en egen amtstue til at varetage oppebørslen af skatterne.

Skulle kongen - mod guvernementets forventning - alligevel ønske at bevare den blandede forfatning, så måtte man som det mindste forlange, at amtmanden over Nordborg Amt og inspektøren på de hertugelige godser på Als fik befaling om at korrespondere med Danske Kancelli i gejstlige sager og modtage befalinger fra samme sted eventuelt med Fyns Stiftsøvrighed som mellemled. På begge øer skulle i så fald udnævnes en amtsprovst. På Als skulle amtsprovsten sammen med amtmanden for Nørreherred og inspektøren på de hertugelige godser udgøre en amtsskoledirektion. På Ærø skulle landfogeden og amtsprovsten være amtsskoledirektion. Begge øers amtsskoledirektioner skulle i givet fald brevveksle direkte med Danske Kancelli. En række yderligere punkter var opregnet. Væsentligst var, hvilken skolelov man skulle indføre på øerne. Guvernementet mente, at man burde overveje, om ikke hertugdømmernes skolelov af 24 . august 1814 var mest passende, da den ville svare til den verdslige forfatning. ${ }^{44}$

Bispedømmet over Als og Ærø oprettedes ved reskript af 21. april 1819. ${ }^{45}$ Reskriptet ligner Fyns Guvernements sidstnævnte, alternative forslag fra 1816 til forveksling. Blot skal »amtsprovst « erstattes af »biskop«. I forestillingen til kongen stod der rent ud, at den nye biskop egentlig var en amtsprovst med biskops navn og rang. Der var også 
Hertug Christian August af Augustenborg (1798-1869). Nogle historikere har ment, at bispedommet Als-Aro blev oprettet af hensyn til hertugen, så han blev fritaget for at forhandle med en så underordnet embedsmand som en amtsprovst. Maleri. Foto $i$ Institut for sønderjysk Lokalhistorie.

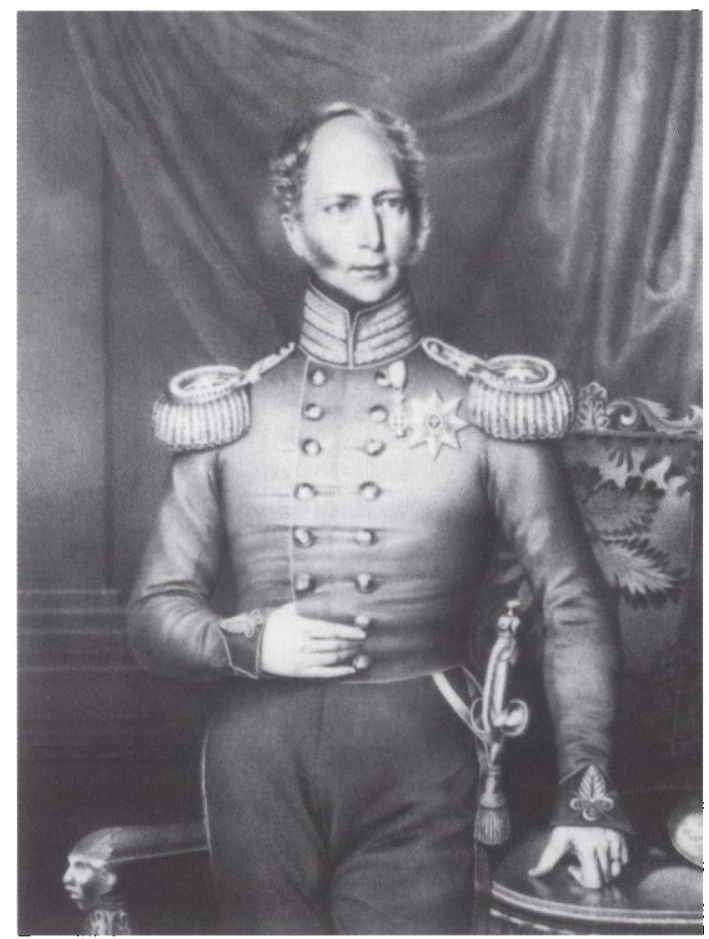

nævnt udvidelsesmuligheder i form af Langeland eller de dansktalende dele af Sønderjylland. ${ }^{46}$

Den eksisterende litteratur om det lille bispedømmes oprettelse siger samstemmende, at ideen kom fra kongen selv. Det er heller ikke udelukket. Men med det alternative løsningsforslag i guvernementets skrivelse fra 1816 var løsningen dog næsten lagt i munden på majestæten, som åbenbart ikke var parat til at følge guvernementets egentlige forslag - om en klar deling af øerne og efterfølgende ensartet gejstlig og verdslig forfatning - men derimod fulgte guvernementets anvisninger på mindstemålet af administrative forandringer.

\section{En administrativ forenkling med et dansk sproghensyn}

Mackeprangs artikel fra 1952 gav den toneangivende teori om bispedømmets oprettelse: bispedømmet oprettedes af hensyn til hertug 
Christian August, så han var fritaget for at forhandle med en så underordnet embedsmand som en amtsprovst. ${ }^{47}$ Man onskede med H. P. Clausens ord at gøre hertugen mere fremkommelig. ${ }^{48}$ Mackeprang lægger vægt på slægtskabet mellem kongehuset og hertugslægten: Frederik VI var morbror til den unge hertug, og kronprins Christian Frederik, som var guvernør på Fyn, var gift med hertugens søster Caroline Amalie.

Mackeprangs forklaring har sin baggrund i forestillingsprotokollen, hvor der står, at "Herved ville opnaas at Hertugen af Augustenborg ikke, med Hensyn til geistlige og Skolesager fik med Fyens Biskop og tillige med en Amtsprovst at gøre men alene med en Biskop, hvorimod han ikke synes at have noget at erindre « ${ }^{49}$ - Tydeligvis ikke et forsøg på at tilfredsstille hertugens krav til rang, men en praktisk løsning: det er lettere at forhandle med én mand end med to.

Den unge hertug Christian August var på studierejse fra juni 1817 til maj $1820 .{ }^{50}$ Han var derfor ikke hjemme, da bispedømmet oprettedes. Løsningen faldt imidlertid ikke $i$ hertugens smag, og næppe var han kommet hjem, før han forsøgte at standse det kommissionsarbejde, som var påbegyndt $\mathrm{i}$ forlængelse af bispedømmets oprettelse. ${ }^{51}$

Det forhindrer dog ikke, at hensynet til hertugen var et reelt motiv til embedsoprettelsen, men kilderne er påfaldende tavse på dét punkt. Sandsynligheden taler derimod for, at man udnyttede hertugens fravær til at få gjort noget ved situationen. En dansk biskop i stedet for en amtsprovst gav jo embedsindehaveren en større frihed, som kunne styrke det danske islæt $\mathrm{i}$ området - og det var ikke til hertugens fordel.

Som vist $\mathrm{i}$ det foregående gjorde forskellige interesser sig gældende i forbindelse med Als og Ærøs jurisdiktionelle tilhørsforhold, gejstligt som verdsligt. Man var nærmest $i$ en fastlåst situation. På den ene side set kunne man ikke lægge Als og Ærø til Slesvig Stift uden at svigte sproghensynet som Ebbesen og Plum påpegede. En ren dansk tilknytning for øerne var på den anden side set for dyr i skatter og kunne skade Ærøskøbings handel. Desuden ville hertugen derved blive reduceret til en almindelig adelig godsejer uden særlige privilegier på Als. Administrativt ville man helst have Als til Slesvig og Ærø til Fyn, da transportforhold besværliggjorde forvaltningen. Kort sagt: der var brug for en kompromisløsning, som kunne skabe en ensartet jurisdiktion og administration - men så langt vovede man ikke at gå.

Et selvstændigt stift gav ikke en ensartet jurisdiktion, men mulig- 
Stephan Tetens (17731855) beklædte som den farste Als-Aro bispestol $i$ arrene 1819-1847. Tetens var ikke blot teolog, men også en lærd klassisk filolog. I 1819 blev han biskop $i$ Ribe, men foretrak embedet som biskop for Als-Aro stift. Her fik han et harmonisk forhold til stiftets præster. Teologisk var han rationalist, $i$ national henseende kæmpede han for dansk sprog og kultur og kom derved $i$ modsætning til hertugen af Augustenborg. Maleri. Foto $i$ Institut for sønderjysk Lokalhistorie.

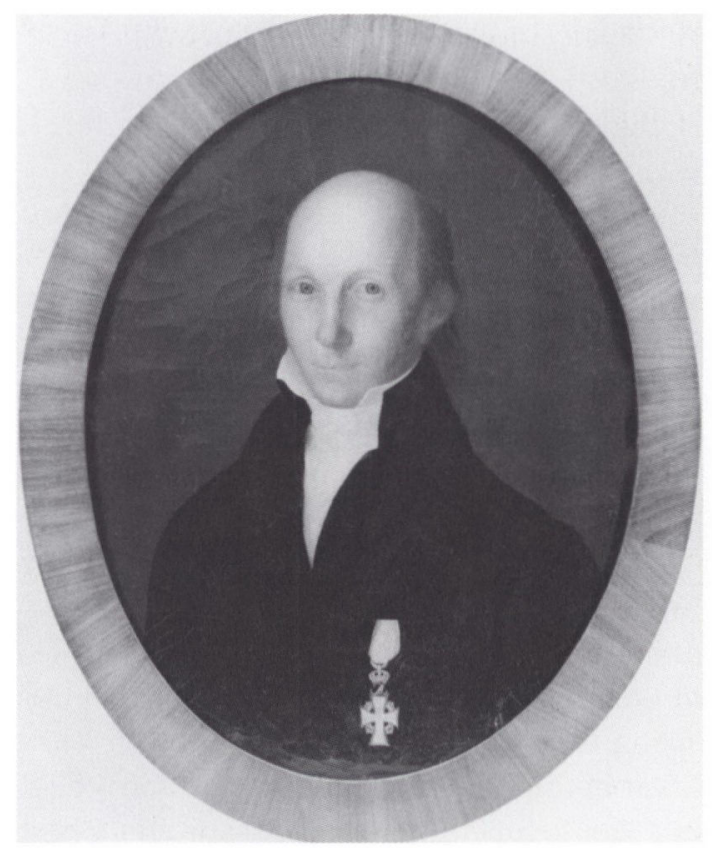

gjorde en større fleksibilitet, så de lovmæssige vanskeligheder kunne mindskes. Det kom blandt andet til syne i 1832, da anordningen om øernes gejstlige bestyrelse udkom: de slesvigske love skulle følges dér, hvor gejstlige love havde berøring med verdslige love. ${ }^{52}$

H. P. Clausen er ikke så kategorisk som Mackeprang: udover af hensynet til hertugen oprettedes bispedømmet også af administrative og sproglige grunde. Man ønskede en forenkling af forretningsgangen - uden at røre ved øernes stilling som en del af Slesvig i civilretlige sager. ${ }^{53}$ Clausen er dermed fremme ved sagens kerne, selv om den noget uklare konklusion kan så tvivl om, hvilket eller hvilke forhold Clausen finder afgørende.

Bispedømmets oprettelse kunne kun have administrative årsager, $\mathrm{da}$ alle involveredes øvrige ønsker opfyldtes ved en fastholdelse af systemet som det var: de danske kirkelove var bedst for præsterne. De sikrede, at der blev ansat danske præster og lærere. Den slesvigske skatteopkrævning var lavere end den danske, og hertugens patronatsrettigheder var ikke i farezonen som systemet var indrettet før 1819.

Når flertallet af præsterne på Als havde sendt en ansøgning til Dan- 
ske Kancelli om en ensartet jurisdiktion, ${ }^{54}$ så skyldtes det ikke utilfredshed med dansk kirkelovgivning som sådan, men derimod vanskelighederne ved at kombinere den danske kirkelovlovgivning med den slesvigske civillovgivning.

Problemet blev forstærket af, at skolelovene fra 1814 ikke var indført på øerne; men også dét skyldtes jo netop sammenstødet mellem gejstlig og verdslig lovgivning. Centraladministrationen havde et stort ønske om, at Danske Kancelli kunne brevveksle direkte med amtmanden på øerne i gejstlige sager, fremfor den tunge forretningsgang via Overretten på Gottorp. Med dannelsen af bispedømmet var der givet mulighed for en forenkling af de administrative forhold, som forårsagedes af den blandede jurisdiktion.

I Fyns Guvernements skrivelse af 23. november 1816 var der med forslaget om en deling af øerne forsøgt at tage hensyn til så at sige alle forhold - også til sprogspørgsmålet. Det sidstnævnte skete i form af en slags hensigtserklæring om, at man skulle sikre, at det danske sprog ikke blev fortrængt på Als. Her var lovgiverne dog afhængige af, at befolkningen selv viste det danske sprog fortsat loyalitet ved at tale det - for administrationssproget $i$ hertugdømmerne var jo tysk. Blev Als taget ud af sin kirkelige fynske tilknytning og lagt til Slesvig Stift, ville det derfor være slut med en dansksproget kirkeforvaltning. Sprogspørgsmålet var altså det eneste uløste problem, hvis øerne deltes mellem Slesvig og Danmark.

Provst Ebbesen - ophavsmanden til sprogproblematikken - som sammen med biskop Plum i Odense havde kæmpet for at bevare dansk som kirke- og skolesprog, blev derfor den virkelige vinder $i$ forbindelse med oprettelsen af bispedømmet for Als og Ærø. Det var nemlig kun af hensyn til hans synspunkt, at øerne ikke blev delt, men forblev samlet med blandet forfatning. En dansk biskop i området kunne ydermere fastholde og styrke det danske præg i kirke og skole.

I den eksisterende litteratur spiller hensynet til hertugen en hovedrolle, når oprettelsen af bispeembedet for Als og Ærø skal forklares. I denne artikel er der derimod argumenteret for, at onsket om en administrativ forenkling af den blandede jurisdiktion var eneafgørende for det nye embedes dannelse. Bispedømmet for Als og Ærø blev ikke oprettet på grund af sprogspørgsmålet - men det var af hensyn til sproget, at administrationen blev forenklet på netop denne måde. 


\section{NOTER OG HENVISNINGER}

1. H. N. A. Jensen: Versuch einer kirchlichen Statistik des Herzogthums Schleswig, bd. 2, Flensburg 1841, 1585.

2. Wilhelm von Rosen (red.): Rigsarkivet og hjolpemidlerne til dets benyttelse, I, 1. bind, København 1983, 253.

3. H. V. Gregersen: Slesvig og Holsten før 1830, København 1981, 450.

4. Gregersen, 1981, 455f.

5. G. Japsen: Det dansksprogede skolevasen $i$ Sonderjylland indtil 1814, Tønder 1968, 15ff.

6. H. N. A. Jensen: Versuch einer kirchlichen Statistik des Herzogthums Schleswig, bd. 1, Flensburg 1840, 312f; 324. Også kirken i Egen havde været udenfor Fyns Stift. Kirken var overgået til Hans den Yngres kirkejurisdiktion som falge af arvedelingen efter Hans den Fldre i 1582. Da Nordborg tilfaldt kronen i 1729/30, overgik Egen Kirke atter til Fyns Stift; i: Jensen, 1841, 1634f.

7. Jensen, 1841, 1624f.

8. H. P. Clausen: "Dansk og tysk på Als 1812-48. I. Bidrag til alsisk skolehistorie«, i: Sønderjyske Arbøger 1965, Aabenraa 1965, 1f; Jensen, 1841, 1599f.

9. H. N. A. Jensen \& A. L. J. Michelsen: Schleswig-Holsteinische Kirchengeschichte, bd. 4, Kiel 1879, 333f.

10. Harald Jørgensen: Lokaladministrationen i Danmark. Oprindelse og historisk udvikling indtil 1970. En oversigt, Kabenhavn 1985, $230 f$.

11. M. Mackeprang: „Biskop Jørgen Hansen. Et Foredrag «, i: Sønderjydske Arboger 1952, Aabenraa 1952, 2ff. Hertugen forhandlede med biskoppen, fordi han havde patronatsret i Sonderherred (jvf. indledningen). Mackeprangs syn uddybes senere.

12. M. Mackeprang: "Sønderjyllands politiske og administrative Forhold", i: Danmarks Kirker. Sonderjylland. Haderslev Amt, første del, København 1954, 39. I Robert Huhle (red.): Bogen om Als, 1956, følger Tage Brummer i sin artikel om "Det alsiske bispedømme 1819-64« Mackeprangs opfattelse så meget, at det pågældende sted i teksten er ren afskrift fra Mackeprangs artikel fra 1952!
13. Anne Riising: „Om Ærøs jurisdiktionsforhold indtil 1866", i: Afhandlinger om Arkiver. Ved Rigsarkivets 75-airs jubilæum 1964, Kobenhavn 1964, 29.

14. N. K. Andersen: »Biskop over Als og Ærø", i: Fyens Stiftsbog 1972, Odense 1972, 49f; Ordbog over det danske Sprog giver ikke grundlag for denne skelnen, da betegnelserne står for det samme, desuden finder man $i$ de samtidige kilder enkelte steder bispedømmet omtalt som et stift.

15. Se herom senere.

16. H. P. Clausen \& Jorgen Paulsen: $A u$ gustenborgerne. Slagt-Slotte-Skxbne, Fra Als og Sundeved, bd. 58, 1980, 247.

17. Rigsarkivet. Tyske Kancelli Indenrigske Afdeling: Slesvig-Holstenske Provinsialregering. 1771-1847. Sager vedr. de kirkelige Forhold paa Als og Ærø, pk. 61 (forkortet: SHP-61), nr. 2, 4/2-1804.

18. SHP-61, nr. 4, 18/12-1804, nr. 5, 15/11805 og nr. 6, 18/1-1805.

19. Clausen, 1965, 2ff; Rigsarkivet. Tyske Kancelli Indenrigske Afdeling: Slesvig-Holsten-Lauenborgske Kancelli. D. Als og Erø Bispedømme. Akter vedr. Regulering af Kirke- og Skoleforhold 1813-33, pk. 161 I: oversigt over forløbet, afsnit I, (der er to pakker, som er forkortet hhv.: AÆB-161 I og II).

20. AÆB-161 I, Plum til Danske Kancelli 11/6-1812.

21. Clausen, 1965, 5; Japsen, 1968, 330.

22. Landsarkivet i Aabenraa: Acta C.IV. Die Herzoglich Augustenburgischen Districte, nr. 93: Regulirung der Gesetzgebung und Administration sowie Schulangelegenheiten Auf Alsen ... 1812-32 (forkortet: C.IV.93), Frid. Christian til Plum 24/9-1812.

23. Clausen, 1965, 11.

24. Rigsarkivet. Danske Kancelli: Danske Cancellies Forestillinger for 1. Departement 1819 (forkortet: DK-1819), nr. 74 og 75, begge af 7/4-1819.

25. Clausen, 1965, 2; Jensen, 1841, 1600.

26. Collegialtidende for Danmark og Norge, Kobenhavn 1809, 376-379. Den senere biskop over Als og Erø, Jørgen Hansen, erindrer imidlertid, at hertugen fik særbehandling, eftersom Frederik 
VI i 1821 ved den første vakance lod sin nevo, den unge hertug Christian August, udstede kaldsbrev; i: »Biskop Jorgen Hansens efterladte Optegnelser om sit Levnet og sit Forhold til Tidens Begivenheder", i: Senderjydske Aarboger 1904, Aabenraa 1904.

27. Hans Schulz: Frederich Christian Herzog zu Schleswig-Holstein. Ein Lebenslauf, Stuttgart/Leipzig 1910, 366ff.

28. C.IV.93, Frid. Christian til Plum 24/91812.

29. C.IV.93, Linstow til overinspektor Petersen 21/9-1812.

30. Clausen, 1965, 10ff; 25; se også biskop Hansens beskrivelse af den unge hertug, i: Biskop Jorgen Hansen, 1904, $55 \mathrm{ff}$.

31. AÆB-161 1, Linstows betænkning til Overretten 21/11-1812.

32. Der henvises især til H.P.Clausen, 1965 og Japsen, 1968.

33. Det ovenstående er hovedsageligt baseret på: Rigsarkivet. Kongehusets Arkiv: Christian 8, pk. 242. Sager vedr. Øerne Als og \#røs gejstlige og verdslige Forfatning 1816-1825 (forkortet: Chr. 8, 242), Ebbesen til Danske Kancelli 29/9-1815 (afskrift af Ebbesen selv), hvor han klart viser sit synspunkt $i$ forbindelse med afvisning af to avisindlæg af G. L. Baden og E. G. I. Fürsen i hhv. Iversens fyenske Avis, nr. 121 (4/9-1815) og Fyens Stifts Adresse-Avis og Avertissementstidende, nr. 144 (21/9-1815).

34. AÆB-161 II, Linstows indberetning 18/11-1814.

35. Sønderherreds syv sogne lå jo under hertugens patronat.

36. Deling af præsteembedets indtægter mellem den nye og tidligere embedsindehaver (eller dennes enke) i det første år efter forflyttelse, afsked eller død.

37. Bortfaldt i kongeriget i 1806.

38. SHP-61, nr. 4, 18/12-1804.

39. Samme monter fremhæves som en vanskelighed for ærøboerne i amtmand Ahlefelds betænkning, SHP-61, nr. 4, 18/12-1804.

40. AÆB-161 II, Danske Kancellis beretning til kongen, 30/10-1816 (genpart).

41. SHP-61, nr. 4, 18/12-1804.

42. AÆB-161 I, Danske Kancelli til Slesvig-Holstenske Kancelli, 30/12-1815; i Chr. 8, 242 finder man i et brev til guvernoren fra Sonderherreds provst Burchardi en glimrende beskrivelse af den tunge forretningsgang, 27/121815.

43. AÆB-161 II, Danske Kancellis beretning til kongen, 30/10-1816 (genpart).

44. AÆB-161 II, genpart til Danske Kancelli af skrivelse fra guvernementet, 23/11-1816.

45. Collegialtidende, København 1819, 315317.

46. DK-1819, nr. 74, 7/4-1819.

47. Mackeprang, 1952, 5.

48. Clausen \& Paulsen, 1980, 247.

49. DK-1819, nr. 74, 7/4-1819.

50. Dansk biografisk Leksikon, s.V.: Christian August, bd. 3, Kobenhavn 1979. 343.

51. AÆB-161 I, Danske Kancelli til Slesvig-Holsten-Lauenburgske Kancelli, 8/8-1820.

52. Anordning, betræffende de geistlige Sagers Behandling og Bestyrelse paa Øerne Als og Ærøe, Kjøbenhavn, den 7. November 1832.

53. Clausen, 1965, 32f.

54. AÆB-161 I, Danske Kancelli til Slesvig-Holsten-Lauenburgske Kancelli, 30/12-1815. 